\title{
Spis powszechny ludności w Królestwie Polskim w 1897 roku$^{*}$
}

ZARYS TREŚCI:

SŁOWA KLUCZOWE:

ABSTRACT:

KEYWORDS:
Celem artykułu jest przedstawienie, w zwięzły sposób, zagadnień związanych z organizacją, przebiegiem i opracowaniem wyników pierwszego spisu powszechnego ludności w Królestwie Polskim. Choć uwagę skupiono na ziemiach Królestwa Polskiego, znajdującego się wówczas pod panowaniem rosyjskim, to prezentowaną problematykę starano się omówić w szerszym aspekcie działalności władz centralnych w Petersburgu. W dorobku polskiej historiografii zagadnienia te poruszano jedynie w ograniczonym zakresie, a nieliczni autorzy zajmowali się przede wszystkim oceną kompletności danych spisowych. spis powszechny ludności z 1897 r., Królestwo Polskie, arkusz spisowy, stan i struktura populacji

The goal of the paper is to concisely show the issues connected with the organization, course and treatment of results of the first general census in the Kingdom of Poland. Although the focus was on the territory of the Kingdom of Poland, under Russian rule at that time, the text seeks to discuss the presented problems from the broader angle of the activities of the central authorities in Petersburg. Polish historiographic texts have discussed these issues only to a limited extent, and the few authors first of all have assessed the completeness of the census data.

general census of 1897, Kingdom of Poland, census form, condition and structure of population 


\section{Wstęp}

Próby gromadzenia danych dotyczących stanu i struktury ludności mają długą tradycję. Informacje zbierano już w starożytności, a szczególnie dobrze rozwiniętym aparatem państwowym w tym zakresie dysponowało Imperium Rzymskie ${ }^{1}$. W średniowieczu sprawozdawczość tego typu osłabła i dopiero w epoce nowożytnej znajomość demografii poszczególnych jednostek administracyjnych stała się istotna dla władz zarówno kościelnych, jak i państwowych. To, co łączyło wszystkie historyczne spisy ludności, to cel, w jakim je sporządzano. Pozyskana wiedza miała być pomocna w sprawnym zarządzaniu państwem, tj. w skutecznym pozyskiwaniu funduszy na jego funkcjonowanie i określeniu możliwości mobilizacyjnych, a tym samym potencjału militarnego ${ }^{2}$.

Nowoczesna koncepcja spisu powszechnego ludności ukształtowała się jednak dopiero w XVIII w. ${ }^{3}$ Pierwszym państwem, w którym przeprowadzono powszechny spis ludności według nowoczesnych kryteriów, była Islandia. Spis odbył się w 1703 r. i miał charakter spisu imiennego. Kolejny spis powszechny ludności przeprowadzono w Szwecji w 1749 r., od tego czasu organizowany był tam co 5 lat. W 1790 r. powszechny spis ludności odbył się w Stanach Zjednoczonych, w 1800 r. we Francji, a w 1801 r. w Anglii, gdzie powtarzano je co 10 lat $^{4}$.

Na ziemiach polskich pierwsze spisy powszechne ludności przeprowadzono w XIX w. Państwo polskie znajdowało się wówczas pod zaborami i ich organizacja spoczywała na aparacie statystycznym poszczególnych państw zaborczych. W cieszącym się znaczną autonomią Księstwie Warszawskim odbyły się

* Pierwotną wersję artykułu stanowi jego wersja angielska, która ukaże się w „Wiadomościach Statystycznych" za rok 2022. Zob. <https://www.ws.stat.gov.pl>.

1 W. Suder, Census populi. Demografia starożytnego Rzymu, Wrocław 2003.

2 Na temat spisów ludności w różnych regionach świata zob. E. Domschke, D. S. Goyer, The Handbook of National Population Censuses: Africa and Asia, New York 1986; D. S. Goyer, E. Domschke, The Handbook of National Population Censuses: Latin America and the Caribbean, North America, and Oceania, New York 1983; D. S. Goyer, G. E. Draaijer, The Handbook of National Population Censuses: Europe, New York 1992; J. Łukasiewicz, Spisy ludności w Polsce i na ziemiach polskich do 1939 r., „Wiadomości Statystyczne” 2009, nr 6, s. 1-5.

3 Powszechny spis ludności powinien spełniać trzy warunki: powszechności (obejmować całą ludność), jednoczesności (musi być przeprowadzony w określonym czasie), imienności (każda osoba ma zostać spisana z imienia i nazwiska). Obecnie w Polsce stosuje się dodatkowo zasady periodyczności (spisy odbywają się, wg zaleceń ONZ, co 10 lat) oraz bezpośredniości (odpowiedzi na pytania spisowe udziela bezpośrednio osoba spisywana, w wyjątkowych sytuacjach jej najbliżsi domownicy). J. Holzer, Demografia, Warszawa 1999, s. 39-44.

${ }^{4}$ G. Thorvaldsen, Censuses and Census Takers. A Global History, New York 2018, s. 20-21. 
dwa spisy powszechne ludności. Oba miały charakter imienny, pierwszy trwał od lipca 1807 r. do końca 1808 r., drugi od października do marca 1810 r. ${ }^{5} \mathrm{~W}$ cesarstwie austriackim pierwszy imienny spis ludności przeprowadzono w $1857 \mathrm{r}$., podobny - w Prusach - w 1840 r. $^{6}$

Przedmiotem artykułu jest spis powszechny ludności w Królestwie Polskim z 1897 r. Królestwo Polskie, utworzone na kongresie wiedeńskim w 1815 r., połączone zostało unią personalną z Rosją i aż do odzyskania przez Polskę niepodległości w 1918 r. było od niej ściśle uzależnione i przez nią kontrolowane. Omawiany spis był jedynym, jaki się odbył w Cesarstwie Rosyjskim przed I wojną światową. Objął on obszar całego Imperium (bez Wielkiego Księstwa Finlandzkiego), nadzorowany był przez instytucje centralne w Petersburgu, stąd poruszane zagadnienia należy rozpatrywać w szerszym ujęciu, nie tylko w odniesieniu do samego Królestwa Polskiego, ale również działań administracji centralnej. $\mathrm{W}$ artykule omówiono przygotowania do spisu, jego organizację i przebieg oraz prace związane z opracowaniem wyników. Celem artykułu nie była natomiast analiza danych statystycznych zebranych $\mathrm{w}$ trakcie spisu?

\section{Geneza i organizacja techniczna spisu}

W carskiej Rosji w drugiej połowie XIX w. kształtowała się nowa rzeczywistość społeczno-gospodarcza, będąca efektem intensyfikacji uprzemysłowienia, urbanizacji, a przede wszystkim reformy uwłaszczeniowej. Weszła ona w życie w 1861 r., na jej mocy chłopi uzyskali m.in. wolność osobistą, a także możliwość awansu społecznego, wzrosła również, choć w ograniczonym stopniu, ich mobilność ${ }^{8}$. W Królestwie Polskim reformę uwłaszczeniową przeprowadzono

5 Szerzej na temat spisów ludności Księstwa Warszawskiego zob. H. Grossman, Struktura społeczna i gospodarcza Księstwa Warszawskiego na podstawie spisów ludności 1808 i 1810 r., Warszawa 1925.

6 J. Lukasiewicz, op. cit., s. 4-5.

7 Oceny wartości zebranych podczas spisu danych ludnościowych dokonał przed laty Stefan Szulc, zob. S. Szulc, Wartość materiałów statystycznych dotyczacych stanu ludności b. Królestwa Polskiego, Warszawa 1920. Zob. też M. Nietyksza, Ludność Warszawy na przełomie XIX i XX wieku, Warszawa 1971; J. K. Janczak, Ludność Łodzi przemysłowej 1820-1914, Łódź 1982; W. Pruss, Skład wyznaniowo-narodowościowy ludności Warszawy w XIX i początkach XX w., [w:] Społeczeństwo Warszawy w rozwoju historycznym, red. J. Kazimierski, Warszawa 1977 , s. $372-388$.

8 A. A. Krnilov, Krest'ânskaâ Reforma, S. Peterburg 1905; B. G. Litvak, Perevorot 1861 goda $v$ Rossii: počemu nerealizovalas' reformatorskaâ al'ternativa, Politizdat, 1991. 
w 1864 r. ${ }^{9}$ Istotnym impulsem, który skłonił władze w Petersburgu do podjęcia decyzji o przeprowadzenia spisu ludności i zdobycia tym samym szczegółowych danych o demografii kraju, były, obok wspomnianych przeobrażeń społecznych, nawarstwiające się problemy związane ze sprawnym zarządzaniem państwem, w tym z koordynacją i skutecznym reagowaniem na wszelkiego rodzaju kryzysy. Znaczące zaniedbania w tym zakresie obnażyła klęska głodu, która wystąpiła w Rosji w latach 1891-1892. Klęska nieurodzaju dotknęła obszar o powierzchni ponad $1400000 \mathrm{~km}^{2}$, głównie w centralnej części Imperium, ziemie w dorzeczu Wołgi, obejmujące prowincje: Niżni Nowogród, Kazań, Riazan, Penza, Tuła, Symbirsk, Saratów, Samara i Tambow. Głodowało wówczas od czternastu do dwudziestu milionów ludzi, z których blisko 400000 zmarło, przeważnie wskutek różnych chorób atakujących wycieńczone głodem organizmy ${ }^{10}$.

Projekt spisu ludności, który objąłby cały obszar Imperium ${ }^{11}$, był już wcześniej przedmiotem dyskusji na I Ogólnorosyjskim Kongresie Statystów, a w 1876 r. był dyskutowany na VIII Sesji Międzynarodowego Kongresu Statystycznego. W lutym 1877 r. projekt regulaminu spisu powszechnego, który został opracowany przez komisję przy Ministerstwie Finansów, przekazano Radzie Państwa, jednak wskutek sprzeciwu części dygnitarzy, a także napiętej sytuacji politycznej (wojna z Turcją w latach 1877-1878) zamierzenia nie doczekały się wówczas realizacji ${ }^{12}$.

Głównym inicjatorem spisu i jego długoletnim propagatorem był Pëtr Petrovič Semënov-Tân-Šanskij, geograf i statystyk, kierownik Centralnego Komitetu Statystycznego w latach 1864-1875 oraz jego bliski współpracownik Nikolaj Aleksan-

9 J. Bardach, B. Leśnodorski, M. Pietrzak, Historia ustroju i prawa polskiego, Warszawa 1994, s. $393-394$.

10 W opinii obserwatorów i komentatorów życia publicznego, tak poważnych skutków klęski głodowej można było uniknąć, pod warunkiem skutecznej współpracy organów centralnych $\mathrm{z}$ administracją lokalną. Kryzys uwypuklił powszechną korupcję, nieskuteczność rządzących i - co ważne - brak orientacji rządu centralnego w realnych problemach prowincji. R. Robbins, Famine in Russia, New York 1975; L. Bazylow, Dzieje Rosji 1801-1917, Warszawa 1970.

11 Rosja pod koniec XIX w. obejmowała obszar ponad $22 \mathrm{mln} \mathrm{km}^{2}$ i była obok Imperium Brytyjskiego najrozleglejszym terytorialnie państwem świata. R. S. Clem, On the Use of Russian and Soviet Censuses for Research, [w:] Research Guide to the Russian and Soviet Censuses, ed. R. S. Clem, Cornell University Press, 2016, s. 19.

12 W latach 1860-1889 na terytorium Imperium Rosyjskiego przeprowadzono 79 spisów regionalnych i w dużych ośrodkach miejskich: Petersburgu (1864, 1869, 1881, 1890), Moskwie (1871, 1882), Twerze (1869), Włodzimierzu, Kazaniu i Kijowie (1874). W Królestwie Polskim odbył się m.in. spis w guberni radomskiej w 1868 r., suwalskiej w 1889 r. i łomżyńskiej w 1890 r. W Warszawie spis taki odbył się w 1882 r. L. Schwartz, A History of Russian and Soviet Censuses, [w:] Research Guide, s. 49-50; M. Nietyksza, op. cit. 
drovič Trojnickij, przewodniczący Rady Statystycznej przy Ministerstwie Spraw Wewnętrznych Rosji ${ }^{13}$. Ostatecznie zamierzenia i plany zostały zaakceptowane dopiero 17 VI 1895 r., uzyskały aprobatę władz, rozpoczęto też prace przygotowawcze. W lipcu 1896 r. ustalono termin spisu, tj. 28 I starego stylu, czyli 9 II (według kalendarza gregoriańskiego) $1897 \mathrm{r}$.

Organem nadzorującym przygotowanie i przeprowadzenie spisu była specjalnie do tych celów powołana Główna Komisja do praw Spisu w Petersburgu. Formalnie podlegała ona Ministerstwu Spraw Wewnętrznych. Niższymi organami podległymi tej komisji były komisje gubernialne i powiatowe; niezależnie od powiatowych tworzono odrębne komisje w niektórych większych miastach. To głównie na komisjach powiatowych ciążył obowiązek podziału powiatu lub miasta na okręgi. Każdy okręg obejmował w miastach ok. 25 tys. mieszkańców, a we wsiach przeważnie jedną gminę. Na czele okręgu stał zarządzający, który dobierał rachmistrzów, kierował ich wyszkoleniem i kontrolował działalność.

Warto zauważyć, że w drugiej połowie XIX w. instytucje w Królestwie Polskim zajmujące się statystyką ludnościową były słabo rozwinięte. W styczniu $1867 \mathrm{r}$. Królestwo Polskie podzielono na 10 guberni: kaliską, kielecką, lubelską, łomżyńską, piotrkowską, płocką, radomską, siedlecką, suwalską i warszawską. W połowie 1868 r. likwidacji uległa Komisja Rządowa Spraw Wewnętrznych, Duchownych i Oświecenia Publicznego - instytucja, która odpowiadała za sprawozdawczość statystyczną związaną z różnymi aspektami funkcjonowania kraju. Od tej pory działalność taka miała należeć do obowiązków redaktorów dzienników gubernialnych wydawanych w każdej guberni. W publikowanych corocznie „Obzorach” podawano bieżące dane o stanie, strukturze i ruchu naturalnym ludności ${ }^{14}$.

Znaczącą rolę w sprawozdawczości statystycznej w Królestwie Polskim w tamtym czasie miał Warszawski Komitet Statystyczny. Kierowana przez prof. G. F. Simonenkę instytucja wzięła także aktywny udział w omawianym spisie z 1897 r. W zamierzeniu kierownictwo Komitetu chciało przejąć jak najwięcej kompetencji związanych z organizacją i przeprowadzeniem spisu, jednak nie

13 T. K. Edlund, The 1st National Census of the Russian Empire, „FEEFHS Journal”, 7 (1999), no. 3-4, s. 91.

${ }^{14}$ J. Berger, Spisy ludności na ziemiach polskich do 1918 r., „Wiadomości Statystyczne”, 2002, nr 2, s. 90; idem, Statystyka w Królestwie Polskim, [w:] Historia Polski w liczbach. Statystyka Polski. Dawniej i dzisiaj, red. F. Kubiczek, Warszawa 2017, s. 85-108; B. Bornstein, Przyczynki do statystyki Królestwa Polskiego. Analiza krytyczna danych statystycznych dotyczacych ruchu naturalnego ludności byłego Królestwa Polskiego, Warszawa 1920. 
wyraziły na to zgody władze w Petersburgu. Znamienne jest jednak to, że inicjatywy podejmowane przez Warszawski Komitet Statystyczny miały wydźwięk propagandowy i były nacechowane postawą prorosyjską, często kosztem odstępstw od prawideł metodycznych badań statystycznych ${ }^{15}$.

Obowiązek zebrania danych spoczywał na rachmistrzach spisowych. Każdy rachmistrz miał do spisania na wsi ok. 400 gospodarstw (ok. 2000 mieszkańców); w mieście ok. 150 mieszkań (750 osób). W Królestwie Polskim powołano blisko 15 tys. rachmistrzów. Rachmistrzami mogły zostać, zgodnie z wytycznymi, osoby dobrze umiejące czytać i pisać, inteligentne i obeznane z miejscowymi stosunkami, o wysokich kwalifikacjach moralnych, cieszące się zaufaniem zarządzającego oraz miejscowej ludności. Przed przystąpieniem do pracy, a po przejściu szkolenia, rachmistrzowie mieli wypełnić na próbę kilka arkuszy spisowych. W Warszawie rachmistrzami byli głównie studenci, na prowincji m.in. lokalni urzędnicy czy nauczyciele ${ }^{16}$. Źródłem informacji dla rachmistrzów miał być wywiad bezpośredni, zabraniano czerpać informacji z innych źródeł. Nagłówki wszystkich rubryk spisu, jak i objaśnienia do kwestionariusza przetłumaczono na języki miejscowe : w sumie na 19 języków. Instrukcje drukowano i tłumaczono $\mathrm{w}$ czasopismach $\mathrm{w}$ celach informacyjnych, a także edukacyjnych ${ }^{17}$. Rachmistrz rozpoczynał pierwszy obchód na wsi na 20-30 dni przed terminem spisu, a w mieście na 5-10 dni przed spisem. Ludność wiejską rachmistrz spisywał osobiście, mieszkańcy dworów i miast sami wypełniali arkusze, które rachmistrz miał każdorazowo sprawdzić. Tak pozyskane informacje miały być sprawdzone w momencie krytycznym spisu. Obchód w dniu spisu rachmistrz miał rozpocząć o świcie, a zakończyć nazajutrz w miastach i najpóźniej po czterech dniach na wsiach ${ }^{18}$.

\section{Arkusze spisowe}

Spis odbywał się według gospodarstw (odrębny arkusz dla każdego gospodarstwa). Nie określono jednak dokładnie terminu „gospodarstwo”. W instrukcji dla

15 Szczególnie wyraźne jest to w kontekście spisywania ludności wyznania greckokatolickiego, a podjęte działania nie pozostały bez wpływu na otrzymane wyniki spisu, np. w przypadku niektórych powiatów guberni siedleckiej.

16 S. Szulc, op. cit., s. 8-10.

17 Wśród ludności krążyły plotki, że poprzez spis władze chcą wprowadzić nowe podatki, że planowane są przesiedlenia na Sybir lub że spis jest zwiastunem przyjścia Antychrysta. Census in Rural Russia, „New York Times”, 12 July 1897, s. 5.

18 S. Szulc, op. cit., s. 7. 
rachmistrzów miejskich uściślono, że to oddzielne mieszkanie, dla wiejskich sformułowania nie określono w ogóle. Pytania spisowe w formularzu w Królestwie Polskim przełożono na język polski i język niemiecki, dodatkowo w guberni suwalskiej na język litewski. W tej kwestii nie wykazano się jednak konsekwencją, co wynikało ze złej woli organizatorów spisu. W przypadku ludności Warszawy formularzy nie przetłumaczono i posługiwano się tylko drukami rosyjskimi. Zgodnie z instrukcją, do arkusza spisowego należało włączyć wszystkie osoby obecne w danym gospodarstwie (także przebywające w nim nie na stałe, a tylko czasowo), jak również stałych mieszkańców, którzy byli nieobecni ze względu na pełnienie obowiązków służbowych. Formularze spisowe przygotowano dla pięciu grup. Formularz pierwszy przeznaczony był dla ludności chłopskiej utrzymującej się z pracy roli. Formularz drugi wypełniała ludność zamieszkująca majątki ziemskie. Trzeci typ formularza wypełniali mieszkańcy miast. Oddzielny druk przygotowano dla ludności wojskowej (12 pytań) oraz studentów zagranicznych, duchowieństwa i podopiecznych organizacji charytatywnych ${ }^{19}$. Podstawowy formularz składał się generalnie z 14 pytań:

1. Nazwisko i imię

2. Płeć (męska, żeńska)

3. Stosunek względem głowy gospodarstwa i względem głowy swojej rodziny

4. Wiek (ile minęło od urodzenia lat lub miesięcy)

5. Stan cywilny (kawaler, żonaty, wdowiec, czy rozwiedziony)

6. Stan, godność albo tytuł

7. Miejsce urodzenia (jeśli inne niż „tutaj”, to jaka gubernia, powiat, miasto)

8. Czy „tutaj” zapisany do ksiąg ludności, a jeżeli nie tutaj, to gdzie?

9. Gdzie zwykle mieszka? Czy „tutaj”, a jeżeli nie, to gdzie (gubernia, powiat, miasto)

10. Zaznaczenie o nieobecności, wyjeździe i czasowym przebywaniu w miejscu spisu

11. Wyznanie

12. Język ojczysty

13. Wykształcenie (a. czy umie czytać; b. gdzie się uczył?)

14. Zajęcie, rzemiosło, przemył, urząd albo służba (a. główne źródło dostarczające środków utrzymania; b. 1. poboczne, 2. stosunek do służby wojskowej.

19 T. K. Edlund, op. cit., s. 91-92. 
Pytania spisowe były jasno sprecyzowane, pewne problemy z jednoznaczną odpowiedzią mogły nastręczać jednak pytania nr 9, 10 oraz 14, tj. dotyczące miejsca zamieszkania (przebywania) oraz wykonywanej profesji. Stefan Szulc, oceniając spis z 1897 r., zwrócił uwagę na niejednoznaczność proponowanych odpowiedzi, ogólnie kwestionariusz ocenił jednak pozytywnie, wskazując jednocześnie na użyteczność i znaczenie zbieranych na za ich pomocą danych: „Mimo wszelkich zastrzeżeń uznać jednak należy, że kwestionariusz w podanej postaci mógł stać się podstawą zupełnie poważnie wykonanej roboty" ${ }^{20}$.

\section{Opracowanie wyników i ich publikacja}

Po zakończeniu zbierania danych, rachmistrz porządkował materiał, dokonywał podsumowań na osobnych formularzach ludności swojej dzielnicy i przekazywał zarządcy okręgu. Ten po sprawdzeniu sporządzał kopie arkuszy; oryginały wysyłano do Petersburga, kopie zostawały w archiwach gubernialnych. Jako dodatkowy organ kontrolny powołano jeszcze „pełnomocników do uzgodnienia czynności spisu". Pełnomocnikiem w Królestwie Polskim został generał porucznik S. I. Tołstoj, a jego pomocnikiem P. A. Baracz (jeden z redaktorów Warszawskiego Komitetu Statystycznego). Do zadań zarządzającego okręgiem należało sporządzenie kopii arkuszy przeprowadzonego spisu. W kolejnym kroku oryginały kart spisowych przesyłano do Petersburga, natomiast kopie deponowano $\mathrm{w}$ archiwach gubernialnych ${ }^{21}$.

W kolejnym etapie pracownicy komisji spisowej w Petersburgu przenosili informacje $\mathrm{z}$ kart spisowych na specjalne karty perforowane, indywidualnie dla każdej z badanych osób, a w ten sposób zakodowane dane były następnie automatycznie analizowane - dostarczając pożądanych zestawień statystycznych. Zajmowali się tym tzw. dietarjusze, pracujący pod kierunkiem kontrolerów i redaktorów. Ci ostatni wyjaśniali wszelkie zaistniałe wątpliwości. Sam proces zliczania przeprowadzono za pomocą maszyn liczących Hermana Holleritha. Taką samą technologię wykorzystano do opracowania spisu powszechnego w Stanach Zjednoczonych w 1890 r. Należy podkreślić, że była to nowatorska technologia i - jak wskazywali sami organizatorzy spisu - bez niej analiza tak olbrzymiej

20 S. Szulc, op. cit., s. 5-6.

21 E. A. Brûhanova, N. P. Ivanova, Dokumentovedčeskij i istočnikovedčeskij analiz pervičnyh materialov Pervoj vseobŝej perepisi naseleniâ Rossijskoj imperii 1897 2., „Vestnik Tomskogo gosudarstvennogo universiteta”, 442 (2019), s. 97-99; S. Szulc, op. cit., s. 7. 
ilości danych w rozsądnym okresie czasu byłaby niemożliwa. Szacuje się, że koszt całego przedsięwzięcia zamknął się w $7 \mathrm{mln}$ rubli ${ }^{22}$.

Publikację wstępnych wyników spisu rozpoczęto jeszcze w tym samym roku, jednak koncepcję głównego wydawnictwa opracowano dopiero po kilku latach. Opublikowane wyniki przedstawiały stan ludności faktycznie obecnej, a także sumarycznie osiadłej, czasowo przebywającej i nieobecnej chwilowo w miejscu spisu. Prezentację tablic oparto na podstawie terytorialnej, w różnym stopniu szczegółowości rzeczowej. Opracowane dane opublikowano w monumentalnym wydawnictwie składającym się z 89 tomów ${ }^{23}$. Każdej guberni poświęcono odrębny tom, składający się ze wstępu oraz z 28 tablic. Dane drukowano w skali powiatów i miast. Królestwa Polskiego dotyczą tomy LI-LX, wydane w 1904 r. (tom LI wydano oddzielnie dla guberni warszawskiej i samej Warszawy). Opublikowane tablice zawierały kolejno informacje:

I. Ludność faktyczna i ludność stała.

II. Podział ludności według gospodarstw i skład tych gospodarstw.

III a. Stan ludności według dziesięcioletnich grup wieku.

b. Podział ludności według płci, wieku (według lat) i umiejętności czytania.

IV. Dzieci młodsze od jednego roku, według liczby miesięcy życia.

V. Podział według stanu rodzinnego i grup wieku.

VI. Podział według grup stanów i miejsca urodzenia.

VII. Podział osób urodzonych nie w miejscu spisu, według miejsca urodzenia.

VIII. Podział ludności według stanów.

IX. Podział ludności według umiejętności czytania, wykształcenia oraz według grup stanów i grup wieku.

22 Do spotkania N. A. Troinitskiego z H. Hollerithem doszło w Petersburgu 15 XII 1896 r. Zgodnie z umową, firma G. Holleritha wydzierżawiła Rosji 35 maszyn liczących, które były już wcześniej używane w innych spisach powszechnych. Były to dosyć skomplikowane w produkcji i drogie urządzenia, stąd zdecydowano się na ich leasing. Dodatkowy potrzebny sprzęt, tj. 70 tabulatorów z maszynami do sortowania i 500 dziurkaczy, został sprzedany do Rosji w konkurencyjnej cenie. Montaż sprzętu odbył się w Petersburgu pod kierownictwem Hermana Holleritha. Zob. O. Anan'eva, Pervaâ vseobŝâ̂ perepis' v Rossii, <http://www.informat444.narod.ru/museum/ pres/pl-6-99.htm> [dostęp: 10.04.2021]; Przedsiębiorstwo Tabulating Machine Company założone przez H. Holleritha w $1896 \mathrm{r}$. dało początek w $1924 \mathrm{r}$ korporacji IBM. Ch. J. Bashe, J. R. Lyle, J. H. Palmer; E. W. Pugh, IBM’s Early Computers, MIT Press 1985.

${ }^{23}$ Pervaâ vseobŝâ̂ perepis' naseleniâ Rossijskoj imperii1897 goda, St. Petersburg 1899-1905, vol. 1-89. 
X. Podział ludności według grup stanów i stanu rodzinnego.

XI. Podział obcych poddanych według państw.

XII. Podział ludności według wyznań.

XIII. Podział ludności według języka ojczystego.

XIV. Podział ludności według wyznań i języka ojczystego.

XV. Podział ludności według języka ojczystego, umiejętności czytania i grup wieku.

XVI. Podział ludności według stanu rodzinnego i języka ojczystego.

XVII. Podział ludności obarczonych ułomnościami fizycznymi, według grup wieku.

XVIII. Podział ludności obarczonych ułomnościami fizycznymi według języka ojczystego.

XIX. Podział ludności obarczonych ułomnościami fizycznym, według grup stanów.

XX. Podział ludności według zajęć i grup wieku.

XXI. Podział według grup zajęć.

XXII. Grupy zajęć i narodowości, na zasadzie języka ojczystego.

XXIII. Podział ludności uprawiającej rolnictwo osiadłe, rolnictwo i pasterstwo koczownicze, rybołówstwo, myślistwo, według zajęć ubocznych.

XXIV. Podział ludności według języka ojczystego i stanów.

XXV. Podział według wyznań i dziesięcioletnich grup wieku.

Niedogodnością publikowanych opracowań jest trudność w dokonywaniu zestawień obejmujących większe obszary. W przypadku Królestwa Polskiego wyodrębniono je w części tablic „Zestawienia ogólnego” ${ }^{24}$. Skład zawodowy ludności opracowano dodatkowo w oddzielnej publikacji. W sumie wyodrębniono ok. 400 różnych zajęć ${ }^{25}$. Opublikowano także kilkanaście mniejszych opracowań uzupełniających, w tym statystykę osad robotników i służby z podziałem na grupy zajęć i miejsce urodzenia.

\section{Ocena wiarygodności zebranych danych}

Dokonując w latach 20. ubiegłego wieku oceny wartości materiałów spisowych, S. Szulc napisał:

24 Zestawienie ogólne rezultatów spisu, vol. 1-2, Petersburg 1905.

25 Podział ludności według rodzajów głównych zajęć i grup wieku w poszczególnych okręgach terytorialnych, vol. 1-4, Petersburg 1904 [Informacje o Królestwie Polskim umieszczono w tomie 3]. 
„Zarzuty, stawiane zazwyczaj spisowi rosyjskiemu, są słuszne: spis przeprowadzono sposobami biurokratycznymi, projekt opracowano zupełnie bez uczestnictwa sił społecznych, powołanie społeczeństwa do uskutecznienia spisu było prawie fikcją. Z roboty wywiązywano się często niedbale, niesumiennie. W samym założeniu były błędy, w opracowaniu ostatecznym brak głębszego planu. [...] Też same rozważania wykazały również, że było to przedsięwzięcie na skalę europejską, czyniące mimo wszystko zadość zasadniczym wymaganiom nauki demografii. Szwankowały raczej czynniki subiektywne, czynniki przedmiotowe, te, które ograniczyć winny do minimum wpływ błędów subiektywnych, na ogół unormowane były bądź co bądź prawidłowo, choć nie idealnie" ${ }^{26}$.

Spośród trzech obiektywnych czynników decydujących o wartości spisu powszechnego ludności, tj. sprawności i dobrej woli organów kierowniczych i wykonawczych, poziomu umysłowego i nastawienia ludności do spisu oraz sposobu opracowania materiału, wedle opinii obserwatorów szczególnie zawodny okazał się czynnik pierwszy. W przypadku Królestwa Polskiego negatywną rolę odegrał niewątpliwie Warszawski Komitet Statystyczny kierowany przez prof. G. F. Simonenkę, którego działania charakteryzowały się porzuceniem obiektywizmu na rzecz postawy prorosyjskiej „dla dobra ojczyzny” w wymiarze propagandowym, co przełożyło się także na większe zainteresowanie i zaangażowanie władz administracji centralnej (np. generała-gubernatora Aleksandra Imeretyńskiego). W czasie samego spisu w 1897 r. raportowano m.in. o takich uchybieniach, jak (raport wspominanego już obserwatora spisu P. A. Baracza): opuszczanie dzieci, niektóre osoby liczono podwójnie, mężczyzn, którzy nie żyli z żonami, raportowano jako wdowców, błędnie raportowano wiek. Wśród generalnych uchybień można wskazać niedokładności w raportowaniu wieku - zaokrąglanie lat, szczególnie do pełnych dziesiątków lat. Starcy podawali zbyt wysoki wiek. Weryfikację przeprowadzono na podstawie dodatkowej dokumentacji. Okazało się, że osób w wieku powyżej 100 lat było 5 razy mniej, niż wynikało ze spisu ${ }^{27}$.

Opuszczenia częściej dotyczyły kobiet niż mężczyzn. Nie zawsze starannie wypełniano dane personalne żon, zdarzało się, że mężowie oświadczali: „Budu â veličat' ee! Baba tak i est', i net ej bol'še nazvaniâ" ${ }^{28}$. Wyznanie raportowano z reguły poprawnie. W Królestwie Polskim przykładem niedokładności z tym związanych może być spis ludności unickiej w guberni siedleckiej. Język

\footnotetext{
26 S. Szulc, op. cit., s. 19

27 Ibidem, s. 19-22.

28 O. Anan'eva, op. cit.
} 
ojczysty raportowano z reguły poprawnie, jednak z wyjątkiem wyznania mojżeszowego, którego wyznawcom przypisywano prawie zawsze język żydowski. Niedokładnie raportowano statystykę zawodów, co związane było z nieprecyzyjnym formularzem (np. kategoria - stanowisko w zawodzie, zajęcie pomocnicze) ${ }^{29}$.

Znamienne wydają się działania władz w stolicy Królestwa Polskiego. Zmierzały one do wykazania znacznego udziału elementu rosyjskiego, co znajduje potwierdzenie w składzie wyznaniowym i podziale według języka ojczystego. W tym celu do ludności miasta zaliczono wojsko skoszarowane, a także rozszerzano obszar Warszawy o miejscowości podmiejskie z dużą liczbą skoszarowanych wojsk. Skład ludności według języka został wypaczony, ponieważ w przypadku ewangelików i żydów kwestionowano podawanie języka polskiego jako ojczystego (skalę tych błędów trudno oszacować). Za wadliwą, jak wyżej wspomniano, można w pewnym stopniu uznać statystykę wieku, co wiązało się z pytaniem $\mathrm{w}$ formularza o liczbę lat, a nie o datę czy rok urodzenia. Zniekształcenia te polegały najczęściej na zaokrąglaniu raportowanego wieku do lat kończących się cyfrą 5 lub pełnych dziesiątek. Błędy stwierdzono także w pytaniach o stanowisko w zawodzie. Uwagę zwraca też zbyt niski udział robotników i służby w ogólnej liczbie ludności, co wynikało m.in. z mieszania zawodu ze stanowiskiem w zawodzie oraz niechęci do przyznawania się do stanowisk najniższych w hierarchii społecznej ${ }^{30}$.

\section{Summary}

\section{The General Census in the Kingdom of Poland in 1897}

The goal of the paper was to discuss the general census of 1897 in the Kingdom of Poland. The study describes its origin, the course of data collection and treatment of results, including decisions taken at the central level.

The idea of a general census that would cover the territory of the whole Russian Empire with the area of ca. 22 million $\mathrm{km}^{2}$ was discussed already in the $1860 \mathrm{~s}$ and 70s. Eventually, the plan was executed in 1897. In the case of the Kingdom do Poland, which was formally one of the provinces of the Russian state, an active role in preparing the census was played by the authorities of individual guberniyas (governorates) as well as by the Warsaw Statistical Committee. The duty to

\footnotetext{
29 S. Szulc, op. cit., s. 19-20.

30 M. Nietyksza, op. cit., s. 218-228.
} 
collect data lay with the administrative authorities at the lowest level, who were responsible, inter alia, for recruiting census representatives. The basic census form consisted of 14 questions. The main reservations about the reliability of the collected data concern the questions about the job position and age, and in the case of the data from the Kingdom of Poland, the falsification of results with regard to respondents' religion and native language being also pointed out.

When using the demographic data of the 1897 census, one should remember the abovementioned oversights or even errors that occurred both at the stage of collection and processing and subsequently the publication of statistical data. A critical research approach to the collected sources permits, however, an effective use of the abundance of the then collected information.

\section{Bibliografia}

Anan'eva O., Pervâ̂ vseobŝâ̂ perepis'v Rossii, <http://www.informat444.narod.ru/ museum/pres/pl-6-99.htm> [dostęp: 10.04.2021].

Bardach J., Leśnodorski B., Pietrzak M., Historia ustroju i prawa polskiego, Warszawa 1994. Bashe C. J., Lyle J. R., Palmer J. H., Pugh E. W., IBM’s Early Computers, MIT Press 1985. Bazylow L., Dzieje Rosji 1801-1917, Warszawa 1970.

Berger J., Spisy ludności na ziemiach polskich do 1918 r., „,Wiadomości Statystyczne” 2002, nr 2, s. 12-19.

Berger J., Statystyka w Królestwie Polskim, [w:] Historia Polski w liczbach. Statystyka Polski. Dawniej i dzisiaj, red. F. Kubiczek, Warszawa 2017, s. 85-108.

Brûhanova E. A., Ivanova N. P., Dokumentovedčeskij i istočnikovedčeskij analiz pervičnyh materialov Pervoj vseobŝej perepisi naseleniâ Rossijskoj imperii 1897 2., ,Vestnik Tomskogo gosudarstvennogo universiteta", 442(2019), s. 96-107.

Census in Rural Russia, „New York Times”, 12 July 1897, s. 5.

Clem R. S., On the Use of Russian and Soviet Censuses for Research, [w:] Research Guide to the Russian and Soviet Censuses, ed. R. S. Clem, Cornell University Press, 2016.

Domschke E., Goyer S. D., The Handbook of National Population Censuses: Africa and Asia, New York 1986.

Edlund T. K., The 1st National Census of the Russian Empire, „FEEFHS Journal”, 7(1999), no. 3-4, s. $88-97$.

Goyer D. S., Domschke E., The Handbook of National Population Censuses: Latin America and the Caribbean, North America, and Oceania, New York 1983.

Goyer D. S., Draaijer G. E., The Handbook of National Population Censuses: Europe, New York 1992. 
Grossman H., Struktura społeczna i gospodarcza Księstwa Warszawskiego na podstawie spisów ludności 1808 i 1810 r., Warszawa 1925.

Holzer Z. J., Demografia, Warszawa 1999.

Janczak J. K., Ludność Łodzi przemysłowej 1820-1914, Łódź 1982.

Krnilov A. A., Krest'ânskaâ Reforma, St. Peterburg 1905.

Litvak G. B., Perevorot 1861 goda v Rossii: počemu nerealizovalas' reformatorskâ̂ al.'ternativa, Politizdat, 1991.

Łukasiewicz J., Spisy ludności w Polsce i na ziemiach polskich do 1939 r., „Wiadomości Statystyczne" 2009, nr 6, s. 1-5.

Nietyksza M., Ludność Warszawy na przełomie XIX i XX wieku, Warszawa 1971.

Pervâ̂ vseobŝâ̂ perepis' naseleniâ Rossijskoj imperii 1897 goda, vol. 1-89, St. Petersburg 1899-1905.

Podział ludności według rodzajów głównych zajęć i grup wieku w poszczególnych okregach terytorialnych, vol. 1-4, Petersburg 1904.

Pruss W., Skład wyznaniowo-narodowościowy ludności Warszawy w XIX i początkach XX w., [w:] Społeczeństwo Warszawy w rozwoju historycznym, red. J. Kazimierski, Warszawa 1977, s. 372-388.

Robbins R., Famine in Russia, New York 1975.

Schwartz L., A History of Russian and Soviet Censuses, [w:] Research Guide to the Russian and Soviet Censuses, ed. R. S Clem, Cornell University Press, 2016.

Suder W., Census populi. Demografia starożytnego Rzymu, Wrocław 2003.

Szulc S., Wartość materiałów statystycznych dotyczących stanu ludności b. Królestwa Polskiego, Warszawa 1920.

Thorvaldsen G., Censuses and census takers. A Global History, New York 2018.

Zestawienie ogólne rezultatów spisu, vol. 1-2, Petersburg 1905. 